удк 796:35.075.5

Петро Рибалко

Сумський державний педагогічний університет імені А. С. Макаренка ORCID ID 0000-0002-6460-4255

Юлія Рашевська

Сумський державний педагогічний університет імені А. С. Макаренка ORCID ID 0000-0003-0761-5107

Вадим Кас'ян

Сумський державний педагогічний

університет імені А. С. Макаренка ORCID ID 0000-0001-8428-0190

DOI 10.24139/2312-5993/2019.08/123-133

\title{
ОСОБЛИВОСТІ УПРАВЛІННЯ ФІЗКУЛЬТУРНО-ОЗДОРОВЧОЮ ДІЯЛЬНІСТЮ В ЗАКЛАДАХ ЗАГАЛЬНОЇ СЕРЕДНЬОЇ ОСВІТИ СІЛЬСЬКОЇ МІСЦЕВОСТІ
}

У статті визначено сутність та зміст фізкультурно-оздоровчої діяльності; визначено функціонування цілісної системи фізичного виховання та оздоровлення в сучасному закладі середньої освіти; проаналізовано зарубіжний досвід управління фізкультурно-оздоровчою діяльністю в закладах середньої освіти. Уточнено поняття «здоров'я», «спосіб життя», «фрізична культура», «фрізична культура школяра»; подальшого розвитку набуло трактування сутності поняття «фізкультурно-оздоровча діяльність» - це заходи, що здійснюються суб'єктами сфрери фрізичної культури і спорту для розвитку фізичної культури.

Наведено аналіз публікацій учених відносно різних аспектів функціонування системи освіти. у дослідженні впроваджено методику управління фрізкультурнооздоровчою діяльністю школи та доведено їі ефективність.

Ключові слова: діти, здоров'я, фізкультурно-оздоровча діяльність, проблеми, перспективи, освіта.

Постановка проблеми. Основними ідеями сучасної освіти, що підтримуються й поширюються Міжнародною організацією ЮНІСЕФ, $є$ ідеї забезпечення прав, свобод та інтересів дітей, представлені в концепції програми «Школа доброзичливого ставлення до дитини» («Child-friendly schools») (Child-Friendly Schools). Вже ні для кого не таємниця, що суспільний запит спрямований на школу, яка $\epsilon$ не тільки місцем, де дітей навчають, а, насамперед, простором для їх повноцінного розвитку, осередком успішних, креативних і щасливих людей. Такий омріяний заклад освіти можливий лише в атмосфері фізичного комфорту, сприятливого соціального та психологічного клімату, що підтримує особистість, яка розвивається, вчасно реагує на ії потреби та з повагою ставиться до її особливостей (Андрущенко, 2004). 
Реформа освіти в Україні набирає обертів. 3 огляду на процес децентралізації влади, перед територіальними громадами постає питання управління освітою. Створення ефективної системи освіти $€$ завданням складним і надзвичайно відповідальним. Тому для освітян важливо мати дієвий інструментарій для цієї роботи (Набок, 2005).

Питання збереження та зміцнення здоров'я $€$ актуальними, оскільки результати наукових досліджень засвідчують стійку негативну динаміку стану здоров'я школярів. Підтвердженням цього може бути достатньо висока кількість дітей із дисгармонійним розвитком, фізіологічною незрілістю, дефіцитом маси й низьким рівнем рухової активності. Актуалізується значення пошуку шляхів оновлення змістово-організаційних аспектів фізкультурно-оздоровчої роботи, спрямованої на задоволення природної потреби дитини в руховій активності, забезпеченні умов для залучення дітей до активного здорового способу життя (Ващенко та Свириденко, 2006).

Одним із шляхів вирішення зазначених проблем в українському суспільстві $\epsilon$ проведення профілактичної діяльності в закладах освіти, прикладом якої може бути системна фізкультурно-оздоровча робота (Бардак та ін., 2008; Ващенко та Свириденко, 2006).

У працях І. Д. Беха, Г. В. Безверхньої, В. Г. Григоренка, Л. П. Іванченка, Л. П. Сергієчка, аргументовано доведено, що фізичне виховання, фізкультурно-оздоровчі педагогічні технології, як складова частина загальної системи освіти, має закласти основи забезпечення й розвитку фізичного здоров'я, комплексного підходу до формування в дітей і підлітків розумової та психологічної підготовки до активного життя і професійної діяльності.

Констатуємо, що проблема розробки й використання педагогічних технологій та організаційно-педагогічних умов з метою формування в дітей і підлітків позитивної мотивації до фізкультурно-оздоровчої діяльності на сучасному етапі розвитку національної освіти не знайшла достатньої науково-методичної розробки.

Аналіз актуальних досліджень. Теоретичною основою дослідження $\epsilon$ праці вітчизняних і зарубіжних фахівців з проблем формування культури здорового способу життя (В. К. Бальсевіч, М. Я. Віленський, О. Л. Трещева); фізкультурно-оздоровчої роботи з дітьми та підлітками в умовах закладів освіти (Л.Л.Головіна, Ю.А. Копилов), за місцем проживання (Г. П. Богданов та ін.); фізкультурно-оздоровчої роботи як однієї з форм людської діяльності, спрямованої на формування повноцінного здорового індивіда (В.І.Жолдак та ін.); розвитку системи позашкільної освіти, активізації виховного потенціалу позашкільних установ (О. В. Биковська, Г.П.Пустовіт), а також у галузі сучасних фізкультурно-оздоровчих технологій - Т. С. Лисицька, Т. Т. Ротерс та ін. 
На сучасному етапі розвитку фізичної культури розробка програм занять оздоровчої спрямованості з використанням найбільш раціональних і доступних засобів і методів фізичної культури набуває особливої актуальності, розробляються методичні підходи щодо вдосконалення фізичної підготовленості і зміцнення здоров'я школярів (О. М. Асташова, В. К. Бальсевич, А. С. Бондарь, О. А. Ващенко та ін.); визначаються найбільш результативні форми організації діяльності школярів, що активізують інтерес до занять фізичною культурою і формують потребу й уміння самостійно займатися фізичними вправами (Б. Ведмеденко, М. Я. Віленський, С. П. Євсеєв, Г.А.Лещенко та ін.); значною мірою в літературних джерелах представлені методичні рекомендації 3 проведення окремих форм фізкультурно-оздоровчої роботи в школі (Т. Штим, О. Дубогай, С. Г. Іванченко, П. П. Миненко та ін.).

Існування великої кількості фізкультурно-оздоровчих програм, які спрямовані на розв'язання різноманітних завдань, у тому числі й підвищення рухової активності школярів, та реальний стан упровадження цих програм у закладах загальної середньої освіти породжує низку проблем (Андрущенко; 2004; Лянной та ін., 2019).

Важливе значення мають наукові погляди В.Г.Григоренка, які відображають базові закономірності реформування, трансформації й оптимізації системи фізичного виховання учнів загальноосвітньої школи. Він довів, що вдосконалення цієї системи повинно здійснюватися на основі принципів індивідуального підходу, пріоритету оздоровчої спрямованості різноманітних освітньо-виховних технологій, широкого використання різноманітних педагогічних технологій формування в дітей і підлітків сталої позитивної мотивації до систематичних занять фізичною культурою, спортом.

Мета роботи - на підставі теоретичного обґрунтування фізкультурнооздоровчої діяльності розробити та впровадити методику управління фізкультурно-оздоровчою діяльністю в закладі загальної середньої освіти сільської місцевості.

Методи дослідження: - теоретичні: аналіз філософських, природознавчих, психологічних і педагогічних джерел, програм, навчальнометодичних посібників, педагогічної документації закладів освіти з метою визначення сутності, змісту, методів, особливостей управління та організації фізкультурно-оздоровчої діяльності в закладі освіти;

- емпіричні: педагогічний експеримент; діагностичні методи (анкетування, бесіда) з метою вивчення стану функціонування предмета дослідження; педагогічне спостереження;

- статистичні: метод елементарної математичної статистики.

Виклад основного матеріалу. Починаючи дану роботу, ми добре розуміли, що особливої уваги вимагає роль директора школи в роботі 3 педагогічним колективом. Робота досягне результатів тільки в тому 
випадку, якщо директор буде вміло спрямовувати та координувати зусилля всіх педагогів, усього колективу й системи формування здорової особистості учня. Директор школи повинен стати центральною фігурою в роботі з оздоровлення учнів. Через класних керівників і педагогівінструкторів спрямовується діяльність усіх органів оздоровчої системи школи за єдиним планом.

Сьогодні суспільство бажає бачити школу не лише одним із освітніх ресурсів, а, скоріше, простором розвитку та співпраці як усередині, так і по відношенню до зовнішнього світу.

Сучасне освітнє середовище створює неповторне індивідуалізоване та персоналізоване враження, де в кожного $є$ можливість відшукати себе. Середовище школи - це місце, де зустрічаються та взаємодіють не лише учні, вчителі, навколишні мешканці та гості школи, де відбуваються не лише уроки, цікаві зустрічі, свята та концерти, але й лекції та семінари, діють відкриті лабораторії і майстерні в різних галузях науки, мистецтва та технологій (Водолазська, 2012).

Вітчизняні та зарубіжні науковці й практики трактують освітнє середовище як частину життєвого, соціального середовища людини, яка виявляється в сукупності всіх освітніх факторів, що безпосередньо або опосередковано впливають на особистість у процесах навчання, виховання та розвитку; $\epsilon$ певним виховним простором, у якому здійснюється розвиток особистості.

Водночас, у сучасних швидкозмінних умовах освітнє середовище закладу освіти не $€$ ізольованим від зовнішніх і внутрішніх факторів, їх впливу, які можуть мати як позитивний результат, так і містити загрози, небезпеки й ризики, які можуть сприяти деструктивним змінам у ньому. Для протидії таким змінам, необхідно, щоб освітнє середовище закладу освіти було захищеним, безпечним.

Організований на базі Уланівського 33 СО I-III ступенів Глухівського району, Сумської області педагогічний експеримент з реалізації методики управління фізкультурно-оздоровчою діяльністю складався з трьох етапів.

На першому етапі передбачалося визначення вихідного стану організації фізкультурно-оздоровчої діяльності закладу освіти.

На другому етапі відбувалося освоєння прийомів фізкультурнооздоровчої діяльності колективом шкільних педагогів і розроблялися перспективні напрями вдосконалення власної фізкультурно-оздоровчої діяльності учнів.

На третьому етапі забезпечувався моніторинг - відстеження результатів цієї діяльності.

За отриманими результатами була розроблена і впроваджена методика коригувальних заходів, спрямованих на поліпшення процесуальних і змістових характеристик фізкультурно-оздоровчої діяльності протягом навчального року. 
Реалізація методики здійснювалася в межах гуманістичної парадигми освіти, що забезпечувало їі культурологічну повноцінність. Це пов'язано 3 тим, що досягнення у сфері здорового способу життя за рахунок привласнення цінності фізичної культури, використовувані в здоров'язбережувальних цілях, розширюють культурологічний простір особистості, освоєння якого стає для школяра морально-виправданою діяльністю.

Урок фізичної культури - єдиний шкільний предмет, що сприяє збереженню та зміцненню здоров'я дітей. Тому 3 уроки фізичної культури на тиждень обов'язкового уроку фізичної культури позитивно позначається на здоров'ї як завдяки підвищенню обсягу рухової активності дітей, так і за рахунок засвоєння й застосування ними на практиці знань про здоров'я, одержаних на цих уроках. Також урок фізичної культури - єдиний урок у шкільному розкладі, що дозволяє хоча б частково компенсувати статичні та психологічні навантаження, які має сучасний школяр у процесі навчання. Доцільність уведення третього уроку фізичної культури на тиждень, а отже, й підвищення обсягу рухової активності школярів, тим більше, при сучасному, найчастіше перевищуючому норматив режимі навчальних і факультативних занять, очевидна за своєю профілактичною цінністю для здоров'я.

у ході дослідження встановлено, що ефективність фізкультурнооздоровчої діяльності школи забезпечується при дотриманні таких педагогічних умов:

1) зміна вихідних принципів організації та управління навчальновиховним процесом;

2) безперервне підвищення професійної компетентності педагогічного колективу в оволодінні методами і технологіями фізкультурно-оздоровчої діяльності;

3) розвиток пізнавальних потреб і мотивацій учнів на оволодіння знаннями основ фізичної культури здорового способу життя;

4) формування ціннісних орієнтацій на заняття оздоровчими фізичними вправами;

5) оптимізація занять фізичними вправами, що забезпечує адаптацію до фізичних навантажень і оздоровчий ефект;

6) перехід від суб'єкт-об'єктних відносин між учителем та учнем у навчально-виховному процесі до суб'єкт-суб'єктних.

Запропонований підхід до управління фізкультурно-оздоровчою діяльністю школи пройшов апробацію й забезпечив досягнення позитивних результатів у підвищенні рівня фізичної культури та здоров'я школярів, розвитку професійної компетентності учителів у сфері здорового способу життя.

Розробка методики управління фізкультурно-оздоровчою діяльністю.

Актуальність методики зі створення системи фізкультурнооздоровчої діяльності в школі полягає, насамперед, у тому, що вона 
орієнтована на вирішення таких значущих проблем, усунення яких у сумі може дати максимально можливий позитивний ефект оздоровлення учнів.

Mema: надання можливостей школі для формування психічно здорової, фізично розвиненої й соціально-адаптованої особистості.

Провідна педагогічна ідея методики полягає в зміцненні та збереженні здоров'я, у формуванні культури здорового способу життя в умовах здоров'язбережувальної системи освіти, у вдосконаленні процесу викладання фізичної культури на основі формування стійкої потреби в руховій активності кожного школяра.

Кінцевий результат упровадження методики: формування й саморозвиток здоров'язбережувального потенціалу фізичної культури особистості, що відповідає логіці особистісно орієнтованої парадигми освіти у сфері фізичної культури.

Пріоритетні напрями управління фізкультурно-оздоровчою діяльністю в загальноосвітніх школах: фізичний розвиток учнів і зміцнення їхнього здоров'я, проблеми залежності здоров'я учнів від способу життя; взаємозв'язок здоров'я людини й екологічної обстановки, психологічний самозахист особистості; правильне та здорове харчування; особиста гігієна; профілактика шкідливих звичок; поведінка в екстремальних ситуаціях; культура здоров'я людини.

Основні напрями педагогічної діяльності у формуванні здорового способу життя учнів (Ващенко, 2006):

- формування цілісного ставлення до здоров'я всіх учасників педагогічного процесу; упровадження традицій, що пропагують і сприяють здоровому способу життя; формування валеологічної культури педагогів, учнів та їхніх батьків; профілактика й корекція соціально шкідливих звичок (тютюнокуріння, алкоголізму, токсикоманії, наркоманії);

- соціально-педагогічна підтримка дітей-інвалідів і дітей групи ризику.

Складові методики фізкультурно-оздоровчої роботи:

- кадрова забезпеченість учителями фізичної культури, медичним персоналом, а також їх кваліфікацією і бажанням підвищувати свою професійну майстерність; форми фізкультурно-оздоровчої роботи; матеріально-технічна база для фізкультурно-оздоровчої роботи (наявність спортивних споруд та їх оснащеність спортивний інвентар); моніторинг фізичного стану учнів; агітація і пропаганда за здоровий спосіб життя.

Методика фізкультурно-оздоровчої роботи в школі включає в себе такі фрорми:

- уроки фізичної культури за затвердженою програмою;

- спортивні секції з видів спорту та ЗФП;

- свята фізичної культури;

- шкільні змагання; 
- дні здоров'я, туристичні походи і зльоти;

- спортивний клуб.

Складності у процесі фізкультурно-оздоровчої роботи:

- відсутність необхідного матеріально-просторового середовища у приміщеннях для занять з оздоровлення учнів, кімнат психологічного розвантаження, ігрових кімнат, фізкультурно-оздоровчих майданчиків, санітарно-гігієнічних кімнат;

- недостатня підготовленість шкільних працівників, батьків із питань збереження та зміцнення здоров'я, формування потреби в учнів здорового способу життя, слабка інформаційна забезпеченість даного напряму «учень-учитель-батько» (Ващенко, 2006).

Одні з цих труднощів можна віднести до об'єктивних, що практично неможливо вирішити в умовах конкретної школи, особливо сільської, й у сучасній соціально-економічній обстановці, і до суб'єктивних, таких, що цілком реалізуються у психолого-педагогічній діяльності. Подолання труднощів стало можливим при виділенні напрямів у системі підготовки й організації виховально-оздоровчої роботи учнів і педагогів.

На організацію фізкультурно-оздоровчої роботи в сільській школі впливають економічні, демографічні, соціальні фактори, які зумовлюють особливий підхід до змісту, організації та методики її проведення.

До специфічних особливостей, що впливає на фізкультурнооздоровчу роботу в умовах сільської нечисленної школи, відносяться мала наповнюваність класу і відсутність паралелі класів, що створює такі проблеми під час організації цієї роботи:

- неможливість виконати навчальну програму 3 рухливих та спортивних ігор в одному класі;

- відсутність стимулу до змагальної діяльності на уроках та можливості для порівняння й оцінки реальних успіхів у спортивних досягненнях;

- відсутність емоційності, привабливості занять;

- психологічна незахищеність дитини, постійний контроль учителя за учнем;

- одноманітність обставин, контактів, форм взаємодії;

- обмежений вибір форм фізкультурно-оздоровчої роботи в навчальній та позанавчальній діяльності.

у зв'язку з цим у сільській школі доцільно й ефективно об'єднання учнів у різновікові групи, що дозволяє успішно вирішувати такі завдання:

- задоволення потреб учнів у виборі форм занять фізкультурнооздоровчої діяльності (навчальної, гурткової, секційної, клубної);

- виявлення індивідуальних можливостей, здібностей кожного школяра і реалізація їх у процесі ігрової, змагальної, спортивної діяльності; 
- розширення контактів, соціальне збагачення взаємодії учнів різного віку;

- виховання фізкультурного активу, здатного виконувати управлінські, організаційні, інформаційні, господарські функції;

- виховання дружного згуртованого спортивного колективу, здатного захищати честь школи на різних змаганнях.

Створення різновікових об'єднань сприяє також вирішенню таких організаційних проблем:

- збільшення кількості занять фізичною культурою без додаткового фінансування і розширення штату вчителів фізкультури;

- включенню в навчальний процес додаткових видів спорту (футболу, туризму, орієнтування на місцевості, настільного тенісу, бадмінтону);

- організації інтегрованих уроків (з природознавством, анатомією, фізикою та іншими предметами);

- проведення занять на природі, поза школою з урахуванням можливостей бази місцевого господарства;

- залучення працівників культурних центрів, медиків, колишніх спортсменів, батьків, місцевих жителів до проведення фізкультурнооздоровчих заходів;

- організації спільних фізкультурно-оздоровчих заходів дітей і дорослих на селі;

- проведення навчальних занять та позанавчальних заходів з учнями прилеглих шкіл, що дозволило школярам проявити себе в новій обстановці і дало можливість порівнювати й оцінювати свої досягнення.

У той самий час аналіз роботи вчителів фізичної культури сільських шкіл дозволив виявити найбільш поширені труднощі в організації діяльності різновікового колективу: проведення навчальних занять одночасно з учнями різного віку; створення різновікової спортивної команди; проведення змагань; регулювання відносин між дітьми різного віку; підготовка фізкультурного активу; взаємодія з учнями на основі діалогу і співпраці; урахування індивідуальних здібностей дітей різного віку у спільній роботі тощо.

Проведення занять у різновікових групах дозволяє учням опановувати навчальний матеріал на якісно новому рівні. Кожен учень на певному етапі навчання, закріплення матеріалу виконує низку педагогічних функцій. Навчаючи, допомагаючи, страхуючи, учень осмислює завдання по-новому, сприймає педагогічний процес по-іншому. Учителю важливо створити атмосферу комфорту як для старших, так і для молодших дітей шляхом підбору навчального матеріалу, різних способів організації діяльності дітей на занятті, засобів і методів для вирішення поставлених завдань із урахуванням можливостей, здібностей і підготовленості учнів різного віку.

Об'єднання класів і проведення занять у різновікових групах дозволяє вчителю вивільнити час для організації позанавчальної 
фізкультурно-оздоровчої роботи, яка при віддаленості сільських шкіл від культурних центрів набуває особливої важливості й обумовлює необхідність створення на селі різновікових спортивних секцій, фізкультурних гуртків, проведення спортивних змагань.

Висновки та перспективи подальших наукових розвідок. У результаті проведеного дослідження:

1. Визначено сутність та зміст фізкультурно-оздоровчої діяльності це заходи, що здійснюються суб'єктами сфери фізичної культури і спорту для розвитку фізичної культури. Метою цієї діяльності $€$ створення сприятливих умов для реалізації права громадян на заняття фізичною культурою і спортом, задоволення їх потреб в оздоровчих послугах за місцем проживання та в місцях масового відпочинку населення.

Основними завданнями фізкультурно-оздоровчої діяльності в школі $€:$ зміцнення та збереження здоров'я школярів; усебічний розвиток фізичних здібностей; поглиблення фізкультурних знань, необхідних для використання в повсякденному житті; формування свідомої мотивації до систематичних занять фізичною культурою.

Фізичну культуру школяра в контексті даного дослідження розуміємо як визначений принцип ставлення школяра до свого здоров'я, до розвитку і збереження можливостей свого організму.

2. Розкрито функціонування цілісної системи фізичного виховання та оздоровлення в сучасній школі і визначено, що найважливішим завданням шкільного фізичного виховання $€$ виховання міцних, здорових молодих людей, які повною мірою опанували навички й уміння, визначені навчальною програмою з фізичної культури.

Фізкультурно-оздоровча діяльність сільської школи як відкрита система набуття особистого досвіду фізичної культури створює передумови для залучення більшості учнів до організованих занять фізкультурою і спортом, дозволяє задовольнити фізіологічно необхідну підліткам норму рухової активності, забезпечити доповнення уроків фізкультури позаурочною спортивно-масовою роботою, що сприяє нормальному розвитку всіх систем і моторики зростаючого молодого організму.

\section{ЛІТЕРАТУРА}

Андрущенко, В. П. (2004). Роздуми про освіmу: стаmmі, нариси, інтерв'ю. К.: Знання України (Andrushchenko, V. Р. (2004). Reflections on education: articles, essays, interviews. K.: Knowledge of Ukraine).

Бардак, 3., Кушнір, О., Штим, Т. (2008). Нетрадиційні методи фізкультурно-оздоровчої роботи. Палітра педагога, 6, 17-20 (Bardak, Z, Kushnir, O., Shtym, T. (2008). Nontraditional methods of physical and health improving work. Educator Palette, 6, 17-20).

Ващенко, О., Свириденко, С. (2006). Готовність вчителя до використання здоров'язберігаючих технологій у навчально-виховному процесі. Здоров'я ma фізична культура, 8, 1-6 (Vashchenko, 0., Svyrydenko, S. (2006). Teacher's 
willingness to use health-saving technologies in the educational process. Health and Physical Education, 8, 1-6).

Водолазська, Т. В. (2012). Модель доброзичливого до дітей освітнього середовища. Пост Методика, 5 (108) (Vodolazska, T. V. (2012). Model of child-friendly educational environment. Post Methodics, 5 (108)). Retrieved from: http://poippo.pl.ua/pm/pdf-1-f-w/PM-108.pdf.

Лянной, М., Рибалко, П., Ганчева, В., Красілов, А. (2019). Методика управління фізкультурно - оздоровчою діяльністю в сучасних закладах середньої освіти. Педагогічні науки: теорія, історія, інноваційні технології, 4 (88), 280-289 (Liannoi, M., Rybalko, P., Hancheva, V., Krasilov, A. (2019). M ethods of management of physical and health-saving activity in modern secondary education institutions. Pedagogical Sciences: Theory, History, Innovative Technologies, 4 (88), 280-289).

Маляр, Е. І. (2009). Методика використання фізичної культури з метою оздоровлення та активного відпочинку. Тернопіль: ТНЕУ «Економічна думка» (Painter, E. I. (2009). M ethods of using physical culture for the purpose of recovery and active rest. Ternopil: TNEU "Economic Thought").

Набок, М. (2005). Проблеми сільської школи та управління нею в процесі реформування освіти в Україні. У В. Ю. Биков, Ю. О. Жук (Ред.), Інформачійні технології і засоби навчання, (сc. 208-222) (Nabok, M. (2005). Problems of the rural school and its management in the process of education reform in Ukraine. In V. Yu. Bykov, Yu. 0. Zhuk (Eds.), Information technologies and teaching aids, (pp. 208-222)).

Національна доктрина розвитку освіти України у XXI столітті: [за док., затв. Указом Президента України від 17 квіт. 2002 р. № 347/2002] (2012). Освітні коментарі, 7/9, 2-10 (The National Doctrine of the Development of Education of Ukraine in the 21st Century: [for Doc. by Decree of the President of Ukraine dated April 17. 2002 No. 347/2002] (2012). Educational Comments, 7/9, 2-10).

Рибалко, П. Ф. (2019). Керівні підходи і принципи у підготовці вчителів фізичної культури до оздоровчо-спортивної діяльності. Гуманізачія навчально виховного прочесу, 4 (96), 66-77 (Rybalko, P. F. (2019). Guiding approaches and principles in the preparation of physical education teachers for health and sports activities. Humanization of educational process, 4 (96), 66-77).

Child-Friendly Schools Documentary Series: Rising Voices. Retrieved from: https:// www.unicef.org/cfs/ index RisingVoices.htm.

\section{PEЗЮМЕ}

Рыбалко Петр, Рашевская Юлия, Касьян Вадим. Особенности управления физкультурно-оздоровительной деятельностью в учреждениях общего среднего образования сельской местности.

В данной статье определена сущность и содержание фризкультурнооздоровительной деятельности; определены функции целостной системы физического воспитания и оздоровления в современном учреждении среднего образования; проанализирован зарубежный опыт управления фризкультурнооздоровительной деятельностью в учреждениях среднего образования.

Уточнено понятие «здоровье», «образ жизни», «физическая культура», «физическая культура школьника»; дальнейшее развитие приобрела трактовка сущности понятия «физкультурно-оздоровительная деятельность» мероприятия, осуществляемые субъектами сфреры физической культуры и спорта для развития физической культуры. 
Приведен анализ публикаций ученых относительно различных аспектов функционирования системы образования. В исследовании внедрена методика управления физкультурно-оздоровительной деятельностью школы и доказана ее эфрфективность.

Ключевые слова: дети, здоровье, физкультурно-оздоровительная деятельность, проблемы, перспективы, образование.

\section{SUM MARY}

Rybalko Petro, Rashevska Yuliia, Kasian Vadym. Peculiarities of physical and healthsaving activity management in general secondary education institutions in rural areas.

This article defines the nature and content of physical and health-saving activities; functioning of a holistic system of physical education and rehabilitation in a modern secondary education institution has been determined; the foreign experience of management of physical and health-saving activity in secondary education institutions is analyzed. The concepts of "health", "lifestyle", "physical culture", "physical culture of a student" have been clarified; interpretation of the essence of the concept of "fitness and health-saving activity" has been further developed. It is interpreted as the measures taken by the subjects of physical culture and sports for the development of physical culture.

The importance of finding ways to update the content and organizational aspects of physical and health-saving work aimed at meeting the child's natural need for physical activity, providing conditions for involving children in an active healthy lifestyle is actualized. One of the ways to solve these problems in Ukrainian society is to carry out preventive activities in education institutions, an example of which can be systematic physical and health-saving work. It is proved that physical education, physical and health-saving pedagogical technologies, as an integral part of general education system, should lay foundations for provision and development of physical health, a comprehensive approach to the formation of mental and psychological preparation for active life and professional activity in children and adolescents.

The analysis of scientists' publications concerning different aspects of the education system functioning is given. The study introduces the method of management of the school physical and health-saving activity and proves its effectiveness.

Key words children, health, physical and health-saving activity, problems, prospects, education

УДК 378/373.2:37.018

Феднова Ірина

Університет імені Альфреда Нобеля

(м. Дніпро)

ORCID ID 0000-0002-5932-7986

DOI 10.24139/2312-5993/2019.08/133-142

\section{ІНТЕРНЕТ-ОРГАНІЗАЦІЯ ПРОСВІТНИЦЬКО-КОНСУЛЬТАТИВНОЇ ДІЯЛЬНОСТІ ЗАКЛАДУ ДОШКІЛЬНОЇ ОСВІТИ}

у статті здійснено дослідження сайтів закладів дошкільної освіти на предмет надання функцій просвітництва та консультування батьків вихованців, визначено найбільш ефективні характеристики Інтернет-організації 